\title{
Halitosis and associated factors in institutionalized elderly persons
}

Maria Cecília Azevedo de Aguiar' Natália Cristina Garcia Pinheiro Karolina Pires Marcelino' Kenio Costa de Lima'

\section{Abstract}

Objective: to evaluate the prevalence of halitosis and associated factors in institutionalized elderly persons. Methods: a sectional study was performed with 268 elderly persons from 11 long-term care institutions in Natal in the northeast of Brazil. Data collection included an oral epidemiologic examination and questions about self-perception of oral health, as well as a consultation of medical records and the application of a questionnaire to the directors of the institutions. Halitosis was measured using the organoleptic test. The independent variables were oral, sociodemographic, institutional, general health and functional conditions. Bivariate analysis was performed using the Pearson chi-square test and Fisher's exact test, and the magnitude of effect was verified by the prevalence ratio for the independent variables in relation to the outcome, with a $95 \%$ confidence level. Results: the prevalence of halitosis was $26.1 \%$, which was exhaled by the mouth in $98.57 \%$ of cases and by the nose in $10 \%$ of cases. Prevalence was $43 \%$ higher among nonwhite individuals $(p=0.006) ; 65 \%$ higher among those living in non-profit institutions ( $p=0.039) ; 52 \%$ higher in elderly persons with oriented cognitive status $(p=0.047) ; 41 \%$ higher in elderly persons with root caries $(p=0.029) ; 62 \%$ higher in those who did not use dentures $(p=0.046) ; 57 \%$ lower in edentulous persons $(p<0.001)$; and $73 \%$ higher in elderly individuals with tongue biofilm $(p=0.001)$. Conclusion: The occurrence of halitosis in institutionalized elderly persons was similar to other studies, but there was an expressive number of extrabuccal cases and an association with oral health problems, as well as sociodemographic, institutional and functional factors.

Universidade Federal do Rio Grande do Norte, Faculdade de Odontologia. Programa de Pós-graduação em Saúde Coletiva. Natal, RN, Brasil.

Correspondence

Maria Cecília Azevedo de Aguiar

E-mail: mariaceciliaaguiar@gmail.com

Keywords: Geriatrics. Elderly. Homes for the Aged. Oral Health. Halitosis. 


\section{INTRODUCTION}

While the global phenomenon of population aging has occurred gradually in developed countries, in developing countries such as Brazil it has occurred in an accelerated manner and in an unfavorable socioeconomic context, resulting in a significant impact on social requirements ${ }^{1}$.

In terms of health the process has resulted in a greater burden of diseases and disability among the population and an increase in the use of health services ${ }^{2}$, notably in terms of an increase in demand for places in Long Term Care Facilities (LTCFs) as a form of social care for the elderly ${ }^{3}$.

Elderly persons living in LTCFs are potentially frail, with a greater risk of multi-morbidities, polypharmacy, immobility and impairments in cognitive ability and functionality ${ }^{4}$.

In terms of oral health, institutionalized elderly persons have more unfavorable oral conditions than those living in the community ${ }^{5,6}$, with a high prevalence of edentulism or periodontal disease and an elevated need for dental extraction and use of dental prostheses identified in several studies in different countries, such as Brazil ${ }^{7,8}$, Spain ${ }^{9}$, Romania $^{10}$, India ${ }^{11}$ and Malta ${ }^{12}$.

It is important to remember that oral problems cause not only pain and discomfort but also have broad repercussions for health. They can predispose individuals to the development of infectious diseases such as endocarditis ${ }^{13}$ and pneumonia ${ }^{10}$, lead to dietary restrictions, weight loss and malnutrition ${ }^{14}$ and also generate impairment in self-esteem and interpersonal relationships, resulting in social isolation and depressive disorders ${ }^{15}$.

Halitosis is defined as a change in the quality of the odor of air exhaled during breathing through the mouth or nostrils, and can range from physiological and adaptive processes to pathological changes. Although it can be caused by extraoral factors such as otorhinolaryngological, gastric, pulmonary and systemic problems, most cases (around 90\% to 95\%) originate from the mouth, and are especially related to the accumulation of tongue biofilm and to periodontal disorders ${ }^{16,17}$.

In addition to an unpleasant odor which results in negative impacts on quality of life ${ }^{15,17}$, halitosis can be a sign of several important systemic diseases such as diabetes, renal and hepatic insufficiency which can directly provoke the problem or function as cofactors ${ }^{16,17}$.

Even oral halitosis, inadvertently considered harmless, can function as a morbidity and mortality factor in institutionalized elderly persons, as their mouths are frequently colonized by a more pathogenic microbiota than that of noninstitutionalized dependent elderly persons, the independent elderly, and young adults ${ }^{18}$. Inadequate saliva and oral hygiene predispose the individual to the accumulation of tongue biofilm, which functions as a potential reservoir for respiratory pathogens. These, when aspirated, reach the lower airways and can result in pneumonia ${ }^{19}$, which represents an even more troubling burden in institutionalized elderly persons due to the higher rates of hospitalization and associated mortality ${ }^{20}$.

In addition, as the mouth is the primary source of halitosis and the oral health of the institutionalized elderly is generally precarious, assessing the breath quality of these individuals has a broader and more inclusive purpose than has been considered by most oral health studies of this group, which focus on the oral health of predominantly edentulous people through the evaluation of the few teeth present, their periodontal condition and the rare use of dentures.

Perhaps because halitosis is understood as a purely cosmetic issue or as a problem that only interferes with social relations which rarely affect the institutionalized elderly, literature on the prevalence of halitosis among this group is scarce. Only one publication $^{21}$ of 124 elderly persons from three LTCFs in Sweden was found, which detected halitosis in $50 \%$ of the subjects examined.

With the aim of contributing to the understanding of this theme, the objective of the present study was to evaluate the prevalence of halitosis and associated factors in institutionalized elderly persons. 


\section{METHODS}

The structure of this study was based on the STROBE22 protocol for observational studies. A population-based cross-sectional study of elderly persons living in the city of Natal, Brazil in 2017 was carried out. At the time, there were 13 institutions registered with the Municipal Sanitary Department, with a population of around 330 elderly persons. Of these institutions, two refused to participate, meaning that 11 took part in the study, of which five were for profit and six were non-profit, resulting in 302 elderly persons eligible to comprise the sample.

The inclusion criteria were: elderly (age 60 and over), reside in a listed LTCF and be in a cognitive condition to collaborate with the necessary procedures for the measurement of breath. The elderly persons were hospitalized or in the process of palliative care. The sample therefore comprised all those who met the eligibility criteria, agreed to participate in the survey and who were present in the institutions on the day of data collection, generating a final sample of 268 elderly people.

Data collection included an oral epidemiological examination of the sample group, based on the SB Brasil $2010^{23}$ model, as well as questions about the oral self-perception of the elderly with oriented cognitive status on the day of the evaluations. In addition, the medical records of the elderly persons were consulted and interviews with institution directors were carried out using a form developed specifically for the study.

For the oral epidemiological examination, complete personal protective equipment, a highpower head torch with zoom function (Albatroz ${ }^{\circledR} /$ ALA-09/made in China), disposable wooden spatulas, gauze, mouth mirrors and previously sterilized WHO millimeter probes were used, along with a clinical data form prepared for the study.

In order to standardizing the understanding, interpretation and application of the evaluated criteria, the examiners were previously trained and calibrated. In this process, the data collection instrument was initially presented and discussed to clarify the details of the variables, codes and criteria of the indices used in the evaluation. Secondly, calibration was carried out by the "in lux" method ${ }^{23}$, by means of the projection and discussion of images of the main oral diseases that affected a population of institutionalized elderly persons evaluated in a survey in the same municipal region in 2013. Good reproducibility between the examiners was observed with values of the coefficients used equal to and over 0.60 considered acceptable.

The data were obtained by three pairs of examiners under the direct supervision of the coordinator. When there was discrepancy in the oral evaluation, the diagnosis was concluded by consensus between the pair of examiners and the coordinator. The evaluation of breath was performed by the coordinator, a dentist with more than ten years of specific experience in the diagnosis and treatment of breath disorders.

The dependent variable of the study was the presence/absence of halitosis, as measured by the organoleptic breath test ${ }^{24}$, where the examiner uses the perception of their sense of smell and qualifies the odor of air eliminated by the patient's mouth and nostrils (respectively) based on a scale of six points, determined by the degree and distance of perception of the odor, with a score of 0 for no odor and 1 for natural odor, indicating the absence of halitosis, and scores of 2 and above representing halitosis (2:mild, 3:moderate, 4 :strong and 5 :severe). When only oral breath is altered and nasal breath is natural, the halitosis is said to be of oral origin, while if the nasal air odor is altered, halitosis is classified as extraoral (either isolated or combined with oral halitosis). Such differentiation is of paramount importance, since it guides the diagnosis and, with it, the treatment of the problem.

The main independent variable was tongue biofilm, recorded as present or absent ${ }^{25}$, and evaluated by thirds of the dorsal lingual surface ${ }^{26}$ (biofilm present only in the posterior third, present in the posterior or middle thirds and visible throughout the dorsal lingual surface).

The independent variables of oral health included the number of decayed and decayed teeth (DMF-T), gingival bleeding, dental calculus, periodontal pocket, root caries, use of dentures and an evaluation of saliva through the signs and symptoms of hyposalivation of the Hyposalivation Detection Questionnaire ${ }^{27}$, 
with nine questions and scores varying from 0 to 9. This is a useful instrument for screening of the need for more thorough saliva examinations. In addition, self-perception of oral health was evaluated by the following questions: When was your last visit to the dentist?; Do you have a problem with your breath?; Do you have a problem with your saliva?

Independent variables related to the LTCFs (both for profit and non-profit) were also evaluated; as were those regarding the sociodemographic characteristics of the elderly persons (age, length of institutionalization, gender, ethnicity/skin color and health plan); their general health (number of morbidities, occurrence of multimorbidities - two or more morbidities diagnosed, diabetes, number of daily medications, occurrence of polypharmacy - use of five or more drugs); of functionality, including cognitive state evaluated by the Pfeiffer index ${ }^{28}$ and categorized (oriented/non-oriented), mobility status and degree of dependence for the performance of activities of daily living (ADL), as measured by the Barthel Index ${ }^{29}$, both with scores of 0 to 100 and categorized (independent/dependent).

Descriptive analysis was performed, followed by bivariate analysis using Pearson's chi-square test and Fisher's exact test, with magnitude of effect verified by the prevalence ratio for each of the independent variables in relation to the outcome at a confidence level of $95 \%$.

The present study was approved by the Ethics Research Committee of the Universidade Federal do Rio Grande do Norte (CAAE 73343717.3.0000.5292, approval $\left.n^{\circ} 2.315 .009\right)$. The elderly participants, their caregivers and curators and the directors of the institutions were informed about the study and those who agreed to participate signed a Free and Informed Consent Form.

\section{RESULTS}

The mean age of the elderly persons was 82.18 years $( \pm 8.610)$, with a mean residence time in the LTCFs of 6.34 years $( \pm 4.914)$. Most were female, of white ethnicity/skin color, did not have health insurance and were residents of non-profit LTCFs (Table 1).
Some degree of cognitive impairment occurred in $92.4 \%$ of the elderly, with a predominance of severe cognitive decline, third-party dependence for some ADLs in $76.7 \%$ of those examined, and some restriction in mobility in $74.6 \%$ of the elderly (table 1 ).

In relation to morbidities, an average of 2.87 $( \pm 1.119)$ diseases per elderly person was observed, of which $29.4 \%$ were diabetes, while $88.1 \%$ of the sample had multimorbidities. Regarding the continuous use of medication, the elderly consumed, on average, $5.62( \pm 2.281)$ drugs/day and $76.5 \%$ of the sample exhibited polypharmacy, as described in table 1 .

In terms of oral conditions, the mean DMF-T index was high and root caries affected almost half of the dentate elderly. Despite the high occurrence of edentulism, most of the elderly did not use any type of dentures to rehabilitate lost teeth (table 2).

The mean number of valid sextants for periodontal evaluation using the community periodontal index was low and the occurrence of excluded sextants was high, so that periodontal evaluation was performed in only a portion of the sample. In these cases, gingival bleeding and dental calculus were found, and there was a prevalence balanced between absent and present periodontal pockets and normal and missing periodontal attachment (Table 2).

There were few cases of signs and symptoms of xerostomia/hyposalivation and positive responses to the question Do you have a problem with your saliva? (table 2).

Regarding oral hygiene condition (table 2), tongue biofilm occurred in most of the elderly persons, covering more than half the surface of the tongue and being mostly thick, with taste buds totally covered by biofilm.

There was a prevalence of general halitosis (perceived as oral, nasal or both simultaneously) of $26.1 \%$ in the sample. Of the elderly persons with halitosis, almost all had bad odor exhaled through the mouth $(98.57 \%$ had oral halitosis alone or concomitant with extraoral) and $10 \%$ through the nostrils (cases of extraoral origin), one of which was nasal odor only (otolaryngologic origin), while six 
others had a simultaneously oral and nasal odor, which indicates oral halitosis concomitant with a gastric, pulmonary or blood-borne etiology. Of the total cases, mild or intimate halitosis predominated. In addition, self-assessment of breath revealed few complaints (table 2).

Table 1. Characterization of elderly persons in relation to sociodemographic, institution-related and general health variables. Natal, Rio Grande do Norte, 2017.

\begin{tabular}{|c|c|}
\hline Variables & $\mathrm{n}(\%)$ \\
\hline \multicolumn{2}{|l|}{ Gender } \\
\hline Female & $195(72.8)$ \\
\hline Male & $73(27.2)$ \\
\hline \multicolumn{2}{|l|}{ Ethnicity/Skin Color } \\
\hline White & $169(67.5)$ \\
\hline Brown & $57(21.5)$ \\
\hline Black & $26(9.8)$ \\
\hline Yellow & $03(1.1)$ \\
\hline \multicolumn{2}{|l|}{ Type of Institution } \\
\hline Non-profit & $180(67.2)$ \\
\hline For profit & $88(38.2)$ \\
\hline \multicolumn{2}{|l|}{ Health Plan } \\
\hline No & $92(66.2)$ \\
\hline Yes & $47(33.8)$ \\
\hline \multicolumn{2}{|l|}{ Multimorbidity } \\
\hline No & $32(11.9)$ \\
\hline Yes & $236(88.1)$ \\
\hline \multicolumn{2}{|l|}{ Diabetes } \\
\hline No & $93(70.6)$ \\
\hline Yes & $39(29.5)$ \\
\hline \multicolumn{2}{|l|}{ Polypharmacy } \\
\hline No & $63(23.5)$ \\
\hline Yes & $205(76.5)$ \\
\hline \multicolumn{2}{|l|}{ Dependence for ADL } \\
\hline Independent & $57(23.3)$ \\
\hline Dependent & $188(76.7)$ \\
\hline \multicolumn{2}{|l|}{ Cognitive state (Pfeiffer) } \\
\hline Intact & $10(7.5)$ \\
\hline Mild Cognitive Decline & $10(7.5)$ \\
\hline Moderate Cognitive Decline & $39(29.3)$ \\
\hline Severe Cognitive Decline & $74(55.6)$ \\
\hline \multicolumn{2}{|l|}{ Cognitive state (binary) } \\
\hline Oriented & $145(54.1)$ \\
\hline Non-oriented & $123(45.9)$ \\
\hline \multicolumn{2}{|l|}{ Mobility } \\
\hline Bedridden & $12(8.7)$ \\
\hline Wheelchair & $37(26.8)$ \\
\hline Walk with assistance & $54(39.1)$ \\
\hline Walk without assistance & $35(25.4)$ \\
\hline Variables & Mean $( \pm$ sd $)$ \\
\hline Age of elderly person & $82.18( \pm 8.610)$ \\
\hline Time in institution & $6.34( \pm 4.914)$ \\
\hline Number of morbidities & $2.87( \pm 1.119)$ \\
\hline Number of drugs & $5.68( \pm 2.281)$ \\
\hline
\end{tabular}


Table 2. Characterization of sample by oral health variables. Natal, Rio Grande do Norte, 2017.

\begin{tabular}{|c|c|}
\hline Variables & $\mathrm{n}(\%)$ \\
\hline $\begin{array}{l}\text { Overall halitosis (oral or nasal) } \\
\text { Absent } \\
\text { Present }\end{array}$ & $\begin{array}{l}198(73.9) \\
70(26.1)\end{array}$ \\
\hline $\begin{array}{l}\text { Oral halitosis (binary) } \\
\text { Absent } \\
\text { Present }\end{array}$ & $\begin{array}{l}199(74.3) \\
69(25.7)\end{array}$ \\
\hline $\begin{array}{l}\text { Oral halitosis (ordinal) } \\
\text { Absence of halitosis } \\
\text { Mild (or intimate) halitosis } \\
\text { Moderate (or interlocutor) halitosis } \\
\text { Severe (or social) halitosis }\end{array}$ & $\begin{array}{l}194(74.0) \\
44(18.8) \\
23(8.8) \\
01(0.4)\end{array}$ \\
\hline $\begin{array}{l}\text { Nasal halitosis (binary) } \\
\text { Absent } \\
\text { Present }\end{array}$ & $\begin{array}{l}259(97.4) \\
07(2.6)\end{array}$ \\
\hline $\begin{array}{l}\text { Problem with halitosis (self-perceived) } \\
\text { No } \\
\text { Yes } \\
\text { No opinion }\end{array}$ & $\begin{array}{l}113(81.9) \\
18(13.0) \\
07(5.1)\end{array}$ \\
\hline $\begin{array}{l}\text { Last visit to dentist } \\
\text { Less than one year } \\
\text { More than one year }\end{array}$ & $\begin{array}{l}27(18.8) \\
117(8.3)\end{array}$ \\
\hline $\begin{array}{l}\text { Gingival bleeding } \\
\text { Absent } \\
\text { Present } \\
\text { Excluded sextant }\end{array}$ & $\begin{array}{l}43(16.7) \\
55(21.3) \\
160(62.0)\end{array}$ \\
\hline $\begin{array}{l}\text { Periodontal calculus } \\
\text { Absent } \\
\text { Present } \\
\text { Excluded sextant }\end{array}$ & $\begin{array}{l}14(5.4) \\
86(33.0) \\
161(61.7)\end{array}$ \\
\hline $\begin{array}{l}\text { Periodontal pocket } \\
\text { Absent } \\
\text { Shallow pocket } \\
\text { Deep pocket } \\
\text { Excluded sextant }\end{array}$ & $\begin{array}{l}54(21.0) \\
33(12.9) \\
09(3.4) \\
160(62.5)\end{array}$ \\
\hline $\begin{array}{l}\text { Loss of Periodontal Attachment (LPA) } \\
0-3 \mathrm{~mm} \\
4-5 \mathrm{~mm} \\
6-8 \mathrm{~mm} \\
9 \mathrm{~mm} \text { or more } \\
\text { Excluded sextant }\end{array}$ & $\begin{array}{l}43(16.8) \\
34(13.3) \\
10(6.6) \\
09(2.7) \\
160(62.5)\end{array}$ \\
\hline $\begin{array}{l}\text { Number of teeth } \\
\text { Number }(0) \\
1-20 \\
>20\end{array}$ & $\begin{array}{l}154(57.5) \\
104(38.8) \\
10(3.7)\end{array}$ \\
\hline $\begin{array}{l}\text { Root caries } \\
\text { Absent } \\
\text { Present }\end{array}$ & $\begin{array}{l}65(56.0) \\
51(44.0)\end{array}$ \\
\hline $\begin{array}{l}\text { Denture } \\
\text { Don't use } \\
\text { Use }\end{array}$ & $\begin{array}{l}181(67.5) \\
87(32.5)\end{array}$ \\
\hline
\end{tabular}


Continuation of Table 2

\begin{tabular}{ll}
\hline Variables & $\mathrm{n}(\%)$ \\
\hline Thick tongue biofilm & $120(46.0)$ \\
No & $141(54.0)$ \\
Yes & $54(20.5)$ \\
Tongue biofilm (binary) & $209(79.5)$ \\
Absent & \\
Present & $56(21.3)$ \\
Tongue Biofilm (thirds) & $39(14.8)$ \\
Absent & $85(32.3)$ \\
Present only in posterior third & $86(31.6)$ \\
Present in posterior and middle thirds & Mean $( \pm$ sd $)$ \\
Present throughout dorsal lingual surface & $28.63( \pm 5.11)$ \\
Variables & $0.66( \pm 1.18)$ \\
\hline DMF-T & $1.86( \pm 2.11)$ \\
\hline Number of sextants CPI and PIP & \\
\hline Xerostomia score $(0$ to 10$)$ & \\
\hline
\end{tabular}

The results of the bivariate analyzes of the occurrence of halitosis and the independent variables showed a significant association between halitosis and ethnicity/skin color, type of LTCF, cognitive status, presence of root caries, use of dentures, edentulism and tongue biofilm accumulation (Tables 3 and 4).

Table 3. Bivariate analysis of the independent sociodemographic and general health variables on the halitosis variable. Natal, Rio Grande do Norte, 2017.

\begin{tabular}{|c|c|c|c|c|}
\hline & $\begin{array}{l}\text { Present } \\
\mathrm{n}(\%)\end{array}$ & $\begin{array}{l}\text { Absent } \\
\mathrm{n}(\%)\end{array}$ & $p$ & PR (CI 95\%) \\
\hline $\begin{array}{l}\text { Age (years) } \\
\text { From } 60 \text { to } 79 \\
80 \text { or more }\end{array}$ & $\begin{array}{l}26(27.7) \\
44(25.3)\end{array}$ & $\begin{array}{l}68(72.3) \\
130(74.7)\end{array}$ & 0.637 & $\begin{array}{l}1.09 \\
(0.72-1.65)\end{array}$ \\
\hline $\begin{array}{l}\text { Time of institutionalization (years) } \\
\text { Up to } 5 \\
\text { Six or more }\end{array}$ & $\begin{array}{l}39(25.0) \\
41(27.0)\end{array}$ & $\begin{array}{l}87(75.5) \\
111(73.0)\end{array}$ & 0.716 & $\begin{array}{l}0.92 \\
(0.61-1.39)\end{array}$ \\
\hline $\begin{array}{l}\text { Gender } \\
\text { Male } \\
\text { Female }\end{array}$ & $\begin{array}{l}22(30.1) \\
48(24.6)\end{array}$ & $\begin{array}{l}51(69.9) \\
147(75.4)\end{array}$ & 0.360 & $\begin{array}{l}1.22 \\
(0.79-1.87)\end{array}$ \\
\hline $\begin{array}{l}\text { Ethnicity/Skin Color } \\
\text { White } \\
\text { Non-white }\end{array}$ & $\begin{array}{l}38(21.2) \\
32(37.2)\end{array}$ & $\begin{array}{l}141(78.8) \\
54(62.8)\end{array}$ & 0.006 & $\begin{array}{l}0.57 \\
(0.38-0.84)\end{array}$ \\
\hline $\begin{array}{l}\text { Type of LTCF } \\
\text { Non-profit } \\
\text { For profit }\end{array}$ & $\begin{array}{l}54(30.0) \\
16(18.2)\end{array}$ & $\begin{array}{l}126(70.0) \\
72(81.8)\end{array}$ & 0.039 & $\begin{array}{l}1.65 \\
(1.01-2.71)\end{array}$ \\
\hline $\begin{array}{l}\text { Health plan } \\
\text { No } \\
\text { Yes }\end{array}$ & $\begin{array}{l}23(25.0) \\
09(19.1)\end{array}$ & $\begin{array}{l}69(75.0) \\
38(80.9)\end{array}$ & 0.438 & $\begin{array}{l}1.30 \\
(0.65-2.59)\end{array}$ \\
\hline $\begin{array}{l}\text { Multimorbidities } \\
\text { No } \\
\text { Yes }\end{array}$ & $\begin{array}{l}08(25.0) \\
62(26.3)\end{array}$ & $\begin{array}{l}24(75.0) \\
174(73.7)\end{array}$ & 0.878 & $\begin{array}{l}0.95 \\
(0.50-1.79)\end{array}$ \\
\hline
\end{tabular}




\begin{tabular}{|c|c|c|c|c|}
\hline & $\begin{array}{l}\text { Present } \\
\mathrm{n}(\%)\end{array}$ & $\begin{array}{l}\text { Absent } \\
\mathrm{n}(\%)\end{array}$ & $p$ & PR (CI 95\%) \\
\hline \multicolumn{5}{|l|}{ Presence diabetes } \\
\hline Yes & $11(28.2)$ & $28(71.8)$ & 0.491 & 1.24 \\
\hline No & $21(26.6)$ & $72(74.4)$ & & $(0.66-2.33)$ \\
\hline \multicolumn{5}{|l|}{ Polypharmacy } \\
\hline No & $16(25.4)$ & $47(74.6)$ & 0.881 & 0.96 \\
\hline Yes & $54(26.3)$ & $151(73.7)$ & & $(0.59-1.56)$ \\
\hline \multicolumn{5}{|c|}{ Dependency for ADL (Barthel) } \\
\hline Independent & $16(28.1)$ & $41(71.9)$ & 0.527 & 1.17 \\
\hline Dependent & $45(23.9)$ & $143(46.1)$ & & $(0.72-1.90)$ \\
\hline \multicolumn{5}{|l|}{ Cognitive state (Pfeiffer) } \\
\hline Intact or mild decline & $02(10.0)$ & $18(90.0)$ & 0.111 & 0.38 \\
\hline Moderate or severe decline & $30(26.5)$ & $83(73.5)$ & & $(0.09-1.45)$ \\
\hline \multicolumn{5}{|l|}{ Cognitive state (binary) } \\
\hline Oriented & $45(31.0)$ & $100(69.0)$ & 0.047 & 1.52 \\
\hline Non-oriented & $25(20.3)$ & $98(79.7)$ & & $(0.99-2.33)$ \\
\hline
\end{tabular}

Table 4. Bivariate analysis of independent oral health variables in relation to the Halitosis variable. Natal, Rio Grande do Norte, 2017.

\begin{tabular}{|c|c|c|c|c|c|}
\hline \multicolumn{6}{|l|}{ Outcome: halitosis } \\
\hline & $\begin{array}{l}\text { Present } \\
\mathrm{n}(\%)\end{array}$ & $\begin{array}{l}\text { Absent } \\
\mathrm{n}(\%)\end{array}$ & $\begin{array}{l}\mathrm{p} \\
\mathrm{n}(\%)\end{array}$ & PR (CI 95\%) & PR (CI 95\%) \\
\hline \multicolumn{6}{|l|}{ Root caries } \\
\hline Present & $19(29.2)$ & $26(51.1)$ & 0.029 & 0.59 & 0.59 \\
\hline Absent & $25(49.0)$ & $46(70.8)$ & & $(0.37-0.95)$ & $(0.37-0.95)$ \\
\hline \multicolumn{6}{|l|}{ Use of dentures } \\
\hline Don't use & $54(29.8)$ & $127(70.2)$ & 0.046 & 1.62 & 1.62 \\
\hline Use & $16(18.4)$ & $71(81.6)$ & & $(0.99-2.66)$ & $(0.99-2.66)$ \\
\hline \multicolumn{6}{|l|}{ "Dry Mouth" complaint } \\
\hline No complaint & $06(24.0)$ & $19(76.0)$ & 0.665 & 0.82 & 0.82 \\
\hline At least one complaint & $11(28.9)$ & $27(71.1)$ & & $(0.35-1.95)$ & $(0.35-1.95)$ \\
\hline \multicolumn{6}{|l|}{ "Dry mouth" complaint } \\
\hline 03 or more positive responses & $16(41.0)$ & $23(59.0)$ & 0.083 & 1.57 & 1.57 \\
\hline None or 02 positive responses & $26(26.0)$ & $74(74.0)$ & & $(0.95-2.60)$ & $(0.95-2.60)$ \\
\hline \multicolumn{6}{|l|}{ Gingival bleeding } \\
\hline Absent & $13(30.2)$ & $30(69.8)$ & 0.317 & 0.75 & 0.75 \\
\hline Present & $22(40.0)$ & $33(60.0)$ & & $(0.43-1.32)$ & $(0.43-1.32)$ \\
\hline \multicolumn{6}{|l|}{ Dental calculus } \\
\hline Absent & $04(28.6)$ & $10(71.4)$ & 0.481 & 0.75 & 0.75 \\
\hline Present & $33(38.4)$ & $53(61.6)$ & & $(0.32-1.77)$ & $(0.32-1.77)$ \\
\hline \multicolumn{6}{|l|}{ Periodontal pocket } \\
\hline Absent & $16(29.6)$ & $38(70.4)$ & 0.267 & 0.73 & 0.73 \\
\hline Present & $17(40.5)$ & $25(59.5)$ & & $(0.83-1.60)$ & $(0.83-1.60)$ \\
\hline \multicolumn{6}{|c|}{ Problems with halitosis (self-perceived) } \\
\hline No & $33(29.2)$ & $80(70.8)$ & 0.407 & 0.71 & 0.71 \\
\hline Yes & $07(38.9)$ & $11(31.1)$ & & $(0.39-1.43)$ & $(0.39-1.43)$ \\
\hline \multicolumn{6}{|l|}{ Problems with saliva } \\
\hline No & $31(30.4)$ & $71(69.6)$ & 0.694 & 1.14 & 1.14 \\
\hline Yes & $08(26.7)$ & $22(73.3)$ & & $(0.58-2.21)$ & $(0.58-2.21)$ \\
\hline
\end{tabular}


Continuation of Table 4

\begin{tabular}{|c|c|c|c|c|c|}
\hline \multicolumn{6}{|l|}{ Outcome: halitosis } \\
\hline & $\begin{array}{l}\text { Present } \\
\mathrm{n}(\%)\end{array}$ & $\begin{array}{l}\text { Absent } \\
\mathrm{n}(\%)\end{array}$ & $\begin{array}{l}\mathrm{p} \\
\mathrm{n}(\%)\end{array}$ & PR (CI 95\%) & PR (CI 95\%) \\
\hline \multicolumn{6}{|l|}{ Presence of teeth } \\
\hline $\begin{array}{l}\text { Edentulous } \\
\text { Toothed }\end{array}$ & $\begin{array}{l}26(16.9) \\
44(38.6)\end{array}$ & $\begin{array}{l}128(83.1) \\
70(61.4)\end{array}$ & $<0.001$ & $\begin{array}{l}0.43 \\
(0.28-0.66)\end{array}$ & $\begin{array}{l}0.43 \\
(0.28-0.66)\end{array}$ \\
\hline \multicolumn{6}{|l|}{ Tongue biofilm } \\
\hline $\begin{array}{l}\text { Absent } \\
\text { Present in three thirds of the dorsum of the tongue }\end{array}$ & $\begin{array}{l}05(8.9) \\
27(32.5)\end{array}$ & $\begin{array}{l}51(91.1) \\
56(67.1)\end{array}$ & 0.001 & $\begin{array}{l}0.27 \\
(0.11-0.67)\end{array}$ & $\begin{array}{l}0.27 \\
(0.11-0.67)\end{array}$ \\
\hline \multicolumn{6}{|l|}{ Tongue biofilm } \\
\hline $\begin{array}{l}\text { Absent } \\
\text { Present (in any region of tongue) }\end{array}$ & $\begin{array}{l}05(9.3) \\
65(31.1)\end{array}$ & $\begin{array}{l}49(90.7) \\
114(68.9)\end{array}$ & 0.001 & $\begin{array}{l}0.29 \\
(0.12-0.70)\end{array}$ & $\begin{array}{l}0.29 \\
(0.12-0.70)\end{array}$ \\
\hline \multicolumn{6}{|l|}{ Thick tongue biofilm } \\
\hline $\begin{array}{l}\text { No } \\
\text { Yes }\end{array}$ & $\begin{array}{l}24(20.0) \\
43(30.5)\end{array}$ & $\begin{array}{l}96(80.0) \\
98(69.5)\end{array}$ & 0.053 & $\begin{array}{l}0.65 \\
(0.42-1.01)\end{array}$ & $\begin{array}{l}0.65 \\
(0.42-1.01)\end{array}$ \\
\hline
\end{tabular}

The prevalence of halitosis was $43 \%$ higher for individuals of non-white ethnicity/skin color than for white individuals; $65 \%$ higher in elderly people residing in non-profit LTCFs than in residents of for profit institutions; $52 \%$ higher in the elderly with an oriented cognitive condition, as opposed to nonoriented; $41 \%$ higher in the elderly with root caries, in comparison with those with no root caries; $62 \%$ higher in the elderly who did not use dentures, in relation to denture users; $57 \%$ lower in the edentulous elderly than in the dentate; and $73 \%$ lower in the elderly without visible biofilm than in those with biofilm on the entire tongue.

\section{DISCUSSION}

The present study corroborates the deficient oral health conditions found by other publications , $^{7,810-12}$, with dental caries causing dental loss and edentulism, resulting in a minor presence of periodontal issues due to the widespread occurrence of excluded sextants. There was also a high prevalence of root caries and low use of dentures (despite significant need) and inadequate access to dental care, based on the majority of the elderly in the study stating that their last visit to the dentist was more than one year ago.

The prevalence of halitosis observed in the present study is in agreement with a meta-analysis ${ }^{30}$ that verified variations in studies with adolescents and adults of between 20 and 55\% and calculated a summary measurement of 31.8\% (95\% CI 24.6$39.0 \%$ ). However, it must be considered that the population groups are completely different.

On the other hand, the prevalence of oral halitosis in a Swedish study with institutionalized elderly persons ${ }^{21}$ was considerably higher than in the present study (50\% x $25.7 \%$, respectively). This was probably due to differences in the oral conditions of Swedish elderly persons in comparison with Brazilians, with the former having a higher presence of teeth, periodontal disease and greater use of dentures. This hypothesis is reinforced by a survey ${ }^{31}$ that compared Brazilian and Spanish institutionalized elderly people, which found precarious oral conditions in both, but with a different profile due to the sociodemographic discrepancies between the countries, where the Spanish sample population had a lower prevalence of edentulism and greater periodontal disease than the Brazilian elderly persons.

The isolated use of the organoleptic test could be considered as a limitation of the presence study, as it is subjective and depends on human standards. However, an article ${ }^{24}$ which summarizes an International Consensus of Halitosis Authorities argues that the use of this test for the diagnosis of halitosis is indispensable, even if detection using instruments is also applied.

The ideal situation would have been to combine the organoleptic test and evaluation with devices 
such as Halimeter ${ }^{\circledR}$ or Oral Chroma ${ }^{\circledR}$. This was attempted in the present study, but the use of such devices was not feasible due to a considerable part of the sample presenting cognitive, mobility and functional limitations, resulting in difficulty in following the steps necessary to performing these exams, such as moving to the environment where the Halimeter ${ }^{\circledR}$ was connected to the electricity, or keeping a straw inside the mouth for the time necessary for the measurement of the gases or, in the case of Oral Chroma ${ }^{\circledR}$, keeping the lips sealed for the time necessary for the collection of air with the syringe device.

In addition, these devices are specific for measuring only sulfur-derived substance ${ }^{24}$, and do not detect organic or aromatic compounds, which play an important role in the etiology of halitosis, especially in disorders of extraoral origin ${ }^{17}$. Thus, if these substances were present and contributed to halitosis, the devices would show false negative results, unlike an organoleptic test carried out by a well-trained and calibrated operator which distinguishes a variety of odors and is also capable of determining the origin of the odor, when performed with nasal and oral air simultaneously.

Based on these considerations, the use of the organoleptic test in the institutionalized elderly persons group is important as it is a quick procedure that is inexpensive, simple to execute and of broad scope - as it depends little on the collaboration of those evaluated, and allows a diagnosis of cases of extraoral origin.

In this context, the present study found a higher occurrence of extraoral halitosis than some estimates in literature ${ }^{16,17}$, which is understandable for people with multimorbidities and polypharmacy and less frequent oral-origin halitosis than estimates of other age groups $s^{16,17,30}$.

Regarding the self-assessment of breath by the elderly persons in the study, complaints of halitosis represented about half the actual prevalence found. It should be emphasized that self-assessment of breath is not reliable, due to a phenomenon called olfactory fatigue, where an individual becomes used to a smell after a certain period of exposure and so can no longer effectively perceive their own breath $^{24}$. Another factor to consider is that selfperception is subjective and has a multidimensional character, and reports by institutionalized elderly people of good and excellent oral conditions is common, despite the precarious situations identified by clinical examination ${ }^{8}$. Finally, a Japanese study ${ }^{32}$ that evaluated institutionalized elderly persons regarding the occurrence of halitosis found that the disorder did not influence their quality of life (measured via SF-36). The confinement of the LTCF environment, with restricted interpersonal relations, and the finding of the present study that most cases of halitosis were of mild intensity, may diminish the psychosocial impact of halitosis and reduce the number of complaints about this condition.

In the present study, two variables (ethnicity/ skin color and type of LTCF) which demonstrated a significant association with halitosis relate to the living conditions of the elderly: there was a higher prevalence of halitosis in non-white elderly individuals living in non-profit LTCFs, while white people predominated in for profit LTCFs and nonwhite people predominated in non-profit LTCFs. The most unfavorable sociodemographic conditions were observed in elderly people living in non-profit $\mathrm{LTCFs}^{33}$, which reflects the social inequality in their lives. Based on this, it is plausible to consider that elderly people with less favorable living conditions have worse health and care situations, favoring the occurrence of halitosis.

From this perspective, it was observed during data collection that only one non-profit LTCF had a dental clinic and, despite possessing the physical structure, its multi-professional team did not include a dentist, meaning dental care was provided through a voluntary service. Moreover, even though they are located in areas covered by the Brazilian public health service, institutionalized elderly persons are not formally included in this system. In contrast, the elderly living in for profit LTCFs had a privileged socioeconomic status, and thus, even in the absence of dentists in the LTCF or access to public services, could visit private dental clinics or pay for home care dental services. In addition, the private institutions offered greater caregiver and health professional support, so that elderly persons in such facilities received better care. 
On the same subject, it was found that none of the LTCFs had a doctor as a member of the clinical staff, so that health assessments occurred on request. Periodic preventive care was therefore rare and ease of access to medical care occurred among the elderly with a health plan or those with favorable socioeconomic conditions, which represented, as a rule, elderly people living in for profit LTCFs. In non-profit institutions, access to medical care was restricted to public health services (which do not include the institutionalized elderly in their coverage), or efforts to meet the financial cost of a private consultation, or to the care provided by volunteers, universities and institutions, which is also occasional and insufficient.

In this context, it is possible that the quality of the information on the diagnosis of morbidities and the use of drugs represents a limitation of this study, since it was obtained through secondary data recorded in the institutional records and, therefore, subject to diagnostic and registration bias. It should be noted that the information on medication use was probably more reliable than that on morbidities, as the former derives from medical prescriptions attached to medical records, while there is not always a medical report contained in the records for the latter.

Another important point to be discussed in the present study is that the prevalence of halitosis was higher in dentate elderly patients with root caries and those who did not use dentures. Such variables are directly related to dental conditions: the sample of the present study was predominantly edentulous and the few dentate elderly persons had root caries and did not generally use dentures, since almost all the dentures used were complete. A study with 115 elderly people from LTCFs in Japan ${ }^{32}$ corroborates the positive association between halitosis and the presence of teeth, while a Swedish study ${ }^{21}$ found associations between halitosis and fixed dentures and periodontal variables, directly related to the presence of teeth.

Regarding halitosis and hyposalivation, a significant association was found in the study by Zellmer et al. ${ }^{21}$, in contrast to the present study, which may be due to the difference in salivary evaluation methods: the Zellmer study used sialometry (the gold standard to assess hyposalivation), while the present study used a questionnaire ${ }^{27}$, which may be considered a limitation.

The greater prevalence of halitosis in the elderly with oriented cognitive status than among the non-oriented is also indirectly related to the presence of teeth and the use of dentures and not only to cognition itself. In the sample of the present study, the oriented elderly retained more teeth and used dentures more frequently than nonoriented individuals (who were generally edentulous and without dentures). In this context, a Swedish study ${ }^{21}$ found an association between halitosis and dementia, although the category "dementia" can be considered vague, as elderly persons in early dementia may have preserved cognition which is affected by other conditions besides dementia.

Regarding halitosis and the presence of tongue biofilm, there was a significant association in the present study, which is corroborated by Aizawa et al. ${ }^{32}$ and other studies ${ }^{16,17}$ for different age groups. Zellmer et al. ${ }^{21}$ did not include analysis of tongue biofilm in their study on halitosis with institutionalized elderly people, and recognized this as a significant limitation.

The high occurrence of tongue biofilm verified in this study is evidence of the likelihood of deficient oral hygiene which, among other consequences, can influence the quality of the breath of the evaluated elderly persons. Due to the high prevalence of edentulism in this group, it is suggested that tongue biofilm is adopted as a routine part of oral health evaluations in this population segment. As well as being an instrument that is simple to understand and apply (which gives it both sensitivity and specificity), it has a universal scope. In addition, the importance of tongue hygiene in the study group should be reinforced with a view to preventing halitosis and other health problems ${ }^{34}$.

The foregoing confirms the relationship between halitosis in the institutionalized elderly and proximal factors, directly related to oral and general health, and distal factors, as halitosis is a reflection of the precarious environment in which these elderly people live and the social inequality they experience during their lives ${ }^{33}$, including prior to institutionalization. 
Public health policies should therefore contemplate actions to promote healthy aging throughout life, but also include the institutionalized - those that have already aged with sequelae - in their coverage in an efficient manner, so that factors related to morbidity and mortality indicators (which include halitosis) are minimized and the elderly not only achieve longevity, but live with quality.

\section{CONCLUSION}

The occurrence of halitosis in the institutionalized elderly was similar to that in studies with other age groups and demonstrated an association with both oral problems and sociodemographic, institutional and functional factors.

It is hoped that the results of the present study will encourage reflections that contribute to the understanding of the oral health of the institutionalized elderly. In the academic environment, it is hoped that it will support other epidemiological studies. As practical approaches should be backed by scientific evidence, it is also estimated that these results will help health services to adopt innovative interventions to improve the oral health of this segment of the population.

\section{REFERENCES}

1. Miranda GMD, Mendes ACG, Silva ALA. O envelhecimento populacional brasileiro: desafios e consequências sociais atuais e futuras. Rev Bras Geriatr Gerontol. 2016;19(3):507-19.

2. Destro JR, Boing AF, D’Orsi E. Fatores associados à realização de consultas médicas por idosos no Sul do Brasil: estudo de base populacional. Rev Bras Epidemiol. 2014;17(3):692-704.

3. Camargos MCS. Instituições de longa permanência para idosos: um estudo sobre a necessidade de vagas. Rev Bras Estud Popul. 2014;31(1):211-7.

4. Wang SY, Shamliyan TA, Talley KM, Ramakrishnan R, Kane RL. Not just specific diseases: systematic review of the association of geriatric syndromes with hospitalization or nursing home admission. Arch Gerontol Geriatr. 2013;57(1):6-26.

5. Souza EHA, Barbosa MBCB, Oliveira PAP, Espíndola J, Gonçalves KJ. Impacto da saúde bucal no cotidiano de idosos institucionalizados e não institucionalizados da cidade do Recife (PE, Brasil). Ciênc Saúde Coletiva. 2010;15(6):2955-61.

6. Eustaquio-Raga MV, Montiel-Company JM, Almerich-Silla JM. Factors associated with edentulousness in an elderly population in Valencia (Spain). Gac Sanit. 2013;27(2):123-7.

7. Piuvezam G, Lima KC. Factors associated with missing teeth in the Brazilian elderly institutionalized population. Gerodontology. 2013;30(2):141-9.

8. Melo LA, Sousa MM, Medeiros AK, Carreiro AD, Lima KC. Fatores associados à autopercepção negativa da saúde bucal em idosos institucionalizados. Ciênc Saúde Coletiva. 2016;21(11):3339-46.

9. Cornejo M, Pérez G, Lima KC, Casals-Peidro E, Borrell C. Oral Health-Related Quality of Life in institutionalized elderly in Barcelona (Spain). Med Oral Patol Oral Cir Bucal. 2013;18(2):285-92.

10. Sfeatcu R, Dumitrache A, Dumitrascu L, Lambescu D, Funieru C, Lupusoru M. Aspects of oral and general health among a community center for the underserved. J Med Life. 2011;4(2):168-71.

11. Shaheen SS, Kulkarni S, Doshi D, Reddy S, Reddy P. Oral health status and treatment need among institutionalized elderly in India. Indian J Dent Res. 2015;26(5):493-9.

12. Santucci D, Attard N. The Oral Health-Related quality of life in state institutionalized older adults in Malta. Int J Prosthodont. 2015;28(4):402-11.

13. Tubiana S, Blotière PO, Hoen B, Lesclous P, Millot $S$, Rudant J, et al. Dental procedures, antibiotic prophylaxis, and endocarditis among people with prosthetic heart valves: nationwide population based cohort and a case crossover study. BMJ. 2017;358:1-9.

14. Serrano-Urrea R, Garcia-Meseguer MJ. Malnutrition in an elderly population without cognitive impairment living in nursing homes in Spain: Study of Prevalence Using the Mini Nutritional Assessment Test. Gerontology. 2013;59(6):490-8. 
15. Lu HX, Chen XL, Wong M, Zhu C, Ye W. Oral health impact of halitosis in Chinese adults. Int J Dent Hyg. 2017;15(4):85-92.

16. Quirynen M, Dadamio J, Van den Velde S, De Smit M, Dekeyser C, Van Tornout M. Characteristics of 2000 patients who visited a halitosis clinic. J Clin Periodontol. 2009;36(11):970-5.

17. Zurcher A, Filippi A. Findings, diagnoses and results of a halitosis clinic over a seven year period. Schweiz Monatsschr Zahnmed. 2012;122(3):205-16.

18. Abe S, Ishihara K, Okuda K. Prevalence of potential respiratory pathogens in the mouths of elderly patients and effects of professional oral care. Arch Gerontol Geriatr. 2001;32(1):45-55.

19. Sumi Y, Miura H, Nagaya M, Michiwaki Y, Uematsu $\mathrm{H}$. Colonization on the tongue surface by respiratory pathogens in residents of a nursing home: a pilot study. Gerodontology. 2006;23(1):55-9.

20. Lim WS, Macfarlane JT. A prospective comparison of nursing home acquired pneumonia with community acquired pneumonia. Eur Respir J. 2001;18(2):362-8.

21. Zellmer M, Gahnberg L, Ramberg P. Prevalence of halitosis in elderly living in nursing homes. Int J Dent Hyg. 2016;14(4):295-300.

22. Von EE, Altman DG, Egger M, Pocock SJ, Gøtzsche PC, Vandenbroucke JP. Strengthening the Reporting of Observational Studies in Epidemiology (STROBE) statement: guidelines for reporting observational studies. BMJ. 2007;40(1):35-53.

23. Brasil. Ministério da Saúde, Secretaria de Atenção à Saúde, Departamento de Atenção Básica. Projeto SB 2010: Condições de saúde bucal da população brasileira no ano 2010. Manual do Coordenador Municipal. Brasília, DF: MS; 2009.

24. Seemann R, Conceição MD, Filippi A, Greenman J, Lenton P, Nachnani S, et al. Halitosis management by the general dental practitioner: results of an international consensus workshop. J Breath Res. 2014;8(1):1-24.

Received: October 16, 2017

Reviewed: October 30, 2017

Accepted: November 07, 2017
25. Quirynen M, Mongardini C, Van Steenberghe D. The effect of a 1-stage full-mouth disinfection on oral malodor and microbial colonization of the tongue in periodontitis patients: a pilot study. J Periodontol. 1998;69(3):374-82.

26. Miyazaki H, Sakao S, Katoh Y, Takehara T. Correlation between volatile sulphur compounds and certain oral health measurements in the general population. J Periodontol. 1995;66(8):679-84.

27. Nunes RS, Pinheiro NCG, Maia ML, Holanda VC, Lima KC. Validação fatorial de questionário para detecção de hipossalivação em idosos institucionalizados. Rev Ciênc Plural. 2015;1(Supl 1):67.

28. Pfeiffer E. A short portable mental status questionnaire for the assessment of organic brain deficit in elderly patients. J Am Geriatr Soc. 1975;23(10):433-41.

29. Mahoney FI, Barthel DW. Functional evaluation: the Barthel Index. Md State Med J. 1965;14:56-61.

30. Silva MF, Leite FRM, Ferreira LB, Pola NM, Scannapieco FA, Demarco FF, et al. Estimated prevalence of halitosis: a systematic review and metaregression analysis. Clin Oral Investig. Epub ahead of print 04 jul. 2017

31. Pessoa DMV, Pérez G, Marí-dell'olmo M, CornejoOvalle M, Borrell C, Piuvezam G, et al. Estudo Comparativo do perfil de saúde bucal em idosos institucionalizados no Brasil e em Barcelona, Espanha. Rev Bras Geriatr Gerontol. 2016;19(5):723-32.

32. Aizawa F, Kishi M, Moriya T, Takahashi M, Inaba $\mathrm{D}$, Yonemitsu M. The analysis of characteristics of elderly people with high VSC level. Oral Dis. 2005;11(Suppl 1):80-2.

33. Pinheiro NCG, Holanda VCD, Melo L.A, Medeiros AKB, Lima KC. Desigualdade no perfil dos idosos institucionalizados na cidade de Natal, Brasil. Ciênc Saúde Coletiva. 2016;21(11):3399-3405. 